\title{
On Cultural Connotation of English and Chinese Animal Words and Their Translation
}

\author{
LU Shu \\ Fuzhou University of International Studies and Trade \\ Fuzhou, Fujian 350202 \\ lillianlu125@163.com
}

\begin{abstract}
The British anthropopogist Edward Taylor mentioned in his book that, culture is the combination of knowledge, belief, arts, laws, morality and customs as well as other capacities and habits that social members need. During the thousands of years, animals have accompanied human races day and night, therefore, many animal words ensued accordingly because of their preference, detest or fright. There are abundant words, phrases and expressions related to animals both in English and Chinese. There are similarities in their meaning while discrepancies still existing as well because of their geographical environment, customs, religion and belief and legend. Because of the equivalence and the inequivalence of the cultural connotation, some animal words have different meaning. In this thesis, parts of the animal words are discussed in the respect of cultural connotation. In the translation process, differences in culture should be taken into consideration to convey the real meaning and style from the sauce language to target language to promote the intercultural communication.
\end{abstract}

Keywords-Animal words; Cultural connotation; Cultural differences; Translation methods

\section{INTRODUCTION}

\section{A. A General Description of Culture}

The noted linguist and anthropologist Edward Sapir wrote this work to show language in "relation to other fundamental interests - the problem of thought, the nature of the historical process, race, culture, art."[1] Language is not only a study of language and culture, but ultimately on the world of relations and influence.language is inter-related with culture. Thus, culture is the first element that should be taken into consideration in translation work, which involves English speaking country's history, culture and tradition, customs, lifestyles and the way they view things, like how they observe the world and how their social opinions, habits as well as behaviour be reflected in language. "Relation to other fundamental interests - the problem of thought, the nature of the historical process, race, culture, art." [1] Language is not only a study of language and culture, but ultimately on the world of relations and influence. Language is inter-related with culture. For example, Chinese people would make blunders like using "a black horse" instead of a black sheep? And use red tea ? Therefore, series of social problems have emerged in interpersonal relationship and the failure to know the basic culture knowledge will triger some shallow mistakes, which is noted by Gao Yihongand $\mathrm{Hu}$ Wenzhong that cultural mistakes are more severe that language mistakes, because it will result in unhappiness in foreigners and Chinese.

\section{B. Cultural Connotations}

"In English and Chinese language, many words carry the meaning related to nationality, religion and society and different metaphors are employed to render them the essential meaning of imagination." [2]In linguistics, English lexicon includes simple words, compounds and idioms. And the meaning of a word includes grammatical meaning and lexical meaning. Lexical meaning has two parts. They are conceptual meaning and cognitive meaning. The former is the center of the meaning of the word, and it indicates definitely the object. Conceptual meaning has comparative stability, so it is also called referential meaning. Cognitive meaning has the meaning of emotional color, it shows emotions and attitudes to the contents that the word refers to. So cognitive meaning is also called connotative meaning. Cultural connotation contains cognitive meanings and cultural meanings. Cultural connotation of a word refers to the cultural information that a word has been given by the society, including the added meaning or the implied meaning given by the social background, and the special feelings conveyed among a certain social group.

\section{CURRENT SituAtion OF THE TRANSLATION OF ANIMAL WORDS}

\section{A. A Comparison of Cultural Connotations of Animal Words in Chinese and English}

The meaning of words is multilevel, conceptual, and connotative. 'The conceptual meaning is the superficial meaning of words while the connotation refers to the real reference and the deluded meaning. "[4] According to the linguistic-domain category, there are three cases in correspondence of Chinese and English animal words. They are basic correspondence, partial correspondence, and no correspondence.

There are various things in the world. Different nations have different views to different objective things, but all human beings have some similar capabilities of thought, some same laws of cognition, and some animals have some same attributes In different languages, some same animals will be endowed with the same or similar images. These images will make different nations have a same or similar association of some ideas. Their usages and meanings both in Chinese and English are basic correspondence or similarity. 


\section{e.g.(1) eat like a wolf 狼吞虎咽 [5]}

\section{(2) fish in trouble water 浑水摸鱼 [5] \\ (3) ride the tiger 骑虎难下 [5]}

(4) parrot what other people say 财鹉学舌 [5]

(5) kill two birds with one stone 一石二乌[5]

The English culture connotations of some animal words carry the same meaning with those of the Chinese cultural connotations of other Chinese animal words. Those words have the same implied meanings, however, their names are different. This is a case that we often have in translation.

e.g. (1) kill the goose that lay golden eggs 杀鸡取卵

(2) as strong as a horse 壮如牛

(3) like a dunk to water 如鱼得水

(4) a drowned rat 落汤鸡

(5) like a cat on hot bricks 热锅上的蚂蚁

(6) Better be the head of a dog than the tail of a lion. 宁为鸡头, 不为凤尾

Because of the differences between the two cultures and image thoughts of the two nations, it's natural that the two nations have different emotional reaction to the same kind of animal. In different cultures and civilizations, the same kind of animal might be given different cultural connotations, which will lead to the vacancy of cultural connotation in the other language, and lead to the obstacles for cross-exchanges. For example, peacock (孔雀) represents “arrogance” in English, but it stands for "beauty" in Chinese. The Chinese think “owl” (猫头鹰) means “ill-omened”, while in English culture, it is viewed as “wisdom”. And “驾鸼” means that husband and wife in Chinese, but "mandarin duck" has not such cultural connotation in English. “山羊” has no special meaning in Chinese, but "goat" means "lecher" in English. In Chinese we have the idiom “指鹿为马”, but the equal expression in English is "talk black into white". The English version of the Chinese saying “挂羊头卖狗肉” is "to cry up wine and sell vinegar".

\section{B. The Causes of the Discrepancy between Cultural \\ Connotation of English and Chinese Animal Words}

The culture of a nation is formed by many factors. And the development of a society influences the formation, the development and the disappearance of the culture. Cultural connotations of some animal words in English and Chinese are closely related to the religion, history, geographical environment, and the customs of a nation. According to these factors, I will take some typical animals for example to elaborate the causes of their discrepancies in Chinese and English.

\section{1) Religion}

We know that there is a big difference between the Chinese religion and the English religion. The Chinese people believe in Buddhism, but the English people believe in Christianity. That is why some animal words about religion are quite different in Chinese and English. For instance, "dragon" and

“龙” have different cultural connotations in the two languages, Chinese and English. In the Chinese culture,

“龙” has been a symbol of “power, being sacred” from ancient times to now. In the feudal society, emperors were addressed with “真龙天子”. To some extent, “龙” is a symbol of China in the world, which stands for the source of the Chinese culture of about five thousand years. It is a special product of the Chinese culture. The Chinese take proud of being “the descendants of dragon” (龙的传人). Some Chinese idioms like “望子成龙”，“龙凤呈祥” are well known to the Chinese. Their meanings contain a commendatory sense. But because of the influence of the Bible, the dragon in westerners' minds is a kind of evil monster, which can vomit fire and sometimes possess three to nine heads. Therefore, there are few idioms and phrases about dragon in English. Generally speaking, in English the word dragon has a derogatory sense when it is used to refer to somebody. Collins Cobuzld English Language Dictionary explains: If you call a woman as a dragon, you mean that she is fierce and unpleasant. So “亚洲四小龙” is often translated as "the four tigers of Asia", not "the four dragons of Asia" . [6]

We have some other idioms that are associated with animals from the Bible:

(1) cast pearl before swine

明珠暗投（把珍珠抛给 猪) 开

(2) separate the sheep from the goats 把好人与坏人分

\section{2) History}

Each nation has its own unique history, which affects the culture of theirs. Meanwhile the history is an important part and factor of each nation's culture.

In Chinese, "ox" has the same meaning as the "horse" in English. That is caused by their different histories. The earliest cultivation mainly depended on "ox" in China, while the heavy farm work was done by "horse" in the early stage of Britain. "Ox" is always a kind of food in Britain, but horse is mainly ridden by people in China. So "ox" of Chinese and "horse" of English are both the same laborious livestock, and they have the same cultural connotations. Today, their functions have more or less changed in these two nations, but their cultural connotations given by history have been carried on as before by their people.

$$
\text { e.g. (1) as strong as a horse 壮如牛 }
$$




\section{(2) work like a horse 像牛一样地辛勤干活}

Some special animal words, idioms come from historical books and classical works, and fable and story are the important components of them.

For example, we have the English idiom “cook one' s goose" . The literal Chinese translation of this idiom is “烹 某人的鹅”. That' s confusing to the Chinese. Its correct translation should be “挫败某人的计划” or “战胜某人”.

This idiom comes from an ancient story. English tradition has it that in The Middle Ages, a city was suddenly surrounded by enemies. A resident of the city hanged a goose on a tower to express his scorn for the enemies. But that was a terribly wrong action. The enemies could not stand this shame. Every soldier became mad, and soon they conquered the city. The goose was cooked by the enemy soldiers. Later, people use the idiom to mean "frustrate somebody's will" or "destroy or defeat somebody".

e.g. If we try hard, we will surely cook their goose.

\section{只要我们努力, 我们肯定就能战胜他们}

We also have some idioms that come from The Fables of Aesop. e.g.

(1) cherish a snake in one' s bosom 养虎贻患

\section{（2） cry wolf 发假警报（烽火戏诸侯）}

\section{3) Geographical environment}

Animal words are closely related to the human work and labour. Different working environments will result in different cultural features. Because of the restrictions of the geographical environment and natural conditions, people will form various habits and have all sorts of life experiences. For example, the Great Britain is a an island country, most of the local people are living by the seashores, and the fishing industry is comparatively developed, therefore, many animal idioms formed are related to $\mathrm{t}$ fish, water and ocean, like a fish (比喻 掲酒掲得很多), the best fish swim near bottom(好鱼居深渊), a shy fish (羞怯的人). However, the Chinese people living in the Asia continent depend on agriculture. Agriculture is the blood tie of the people, and cattle, horses and 驴 are the helpers of the agricultural work, which contributes to the forming of the Chinese animal idioms. Like 老黄牛 (he who works diligently), 千里马 (he who is talented), 笨驴 ( he who is as foolish as a donkey), etc.

The differences between the geographical environments of the two nations make many animals' images and cultural connotations different or even vacant.

e.g. Beavers (河狸) mainly live in North America. They build their nests with high techniques and inflexible will. People of American countries are familiar with this kind of animal. So in English "beaver" means "the people who work hard" . As the geographical environments in China are quite different, the Chinese people hardly know this kind of animal and their special cultural connotations. They don't know their "diligence" and what they really mean sometimes. Hence, if you translate beaver literally, sometimes you can not make the original understood by the Chinese people.

e.g. (1) They didn' t study hard at ordinary times. So when the examination came, they had to work like beavers. 由 于平时不努力, 考试来临时, 他们就不得不日夜苦读了

(2) We often beaver away at school. 我们常在学校

\section{里用功读书}

As we know, Britain is a typical island country. The navigable industry and marine products of Britain are developed. So, some animal words, idioms, proverbs about ocean and marine aquatics are plentiful and popular. But the living environments of the Chinese nation have been restricted mainly to the mainland. Comparatively speaking, the Chinese animal words about ocean and marine aquatics are fewer than Britain's. Sometimes, they might even make cultural vacancy in translation. For example, in English "fish" has rich cultural connotations while in Chinese it doesn't.

e.g. (1) a pretty kettle of fish. 一团糟

(2) to fish in the air 水中捞月

(3) to have other fish to fry 有别的事要干

Also, in English "fish" can be used to refer to "person".

e.g. (1) an odd fish 怪人

(2) a loose fish 放荡不羁的人

(3) a poor fish 可怜虫或倒䨢的家伙

(4) a fish wife 没教养的女人

(5) a cold fish 冷酷无情的人

(6) a big fish 大人物

\section{4) Customs}

The words and idioms about dog even reflect more the dissimilarity between the English customs and the Chinese customs. Both the English-speaking people and the Chinese people like raising dogs, but their aims and attitudes towards dogs are quite different. take "dog", which is derogatory in Chinese culture for example, it means people who flatter as well as the group of people who are good at flattering in order to achieve their purpose. However, in English culture, the dog is regarded as pets and the best friends of human beings, which is obviously reflected in some familiar idioms like "Love me, love my dog", "a lucky dog" [7], to name just a few., in English-speaking countries, dogs are generally persons' companions, it carries the meaning of honesty and just few dogs are raised to hunt or look after the house. Some people have no children, and their dogs can take the place of children. Dogs often have preferential treatments, even "privileges". Their food, clothes are no less good as their masters'. They 
even can listen to some songs specially created for them. They can see a veterinary surgeon when they are ill. They can also enjoy a "vacation" when their hosts spend their holidays. These customs of raising dogs are common in Western countries. Westerners sometimes use the animal word dog to refer to their friends. But this behavior makes the Chinese puzzled. In China, dogs usually do not "enjoy" this kind of treatment. In the Chinese culture, dogs are disgusting, and the word dog often has a derogatory sense, especially when used to refer to a person. Generally speaking, the Chinese despise this kind of animal in heart. They breed them just for hunting and looking after the house. I believe these customs will not change in a short time.

\section{e.g. (1) a lucky dog 幸运儿 \\ (2) Every dog has his day 人人都有得意时 \\ (3) Love me, love my dog. 爱屋及乌}

In English we have some other animal words and expressions that are connected with traditional customs:

(1) carry owls to Athens 运猫头鹰到雅典; 多此一 举 (The reason is that Athens is rich in owls)

(2) As well be hanged for a sheep as for a lamb 一不 做,二不休 (The reason is that a former British law had this rule: a person who steals a sheep, whether the sheep is big or not, will be hanged.)

(3) Live like a fighting cock 吃最好的东西;养尊处

优 (The reason is that in the past, Englishmen would give their fighting cocks the best food before the game so that they could win the game.)

\section{TRANSLATION SKILLS TO BE EMPLOYED}

Above all, many objects have superficial or profound meaning beneath the idiom words meaning. And these meanings are generated from the inseparable cultural backgrounds. Therefore, as Krashen mention in his Affective Filter Hypothesis and Spoken English Teaching. "Second language learners should input his emotion inlto his translation work. The new research also shows that; Success $=15 \% \mathrm{IQ}+$ $85 \%$ EQ." [9] It is of great importance to know the connotation of words, particularly in the translation work.

\section{A. Substitution}

Both China and the U.K. have a long time history in language, and the idiom words in these two languages reflect the unique features of their own national cultures and histories. Therefore, some idioms of the source language may not find the exactly equivalent words in the target language.

For example, tiger (虎) refers to “prowess, solemn and might" [11] in Chinese. We have so many examples of Chinese idioms that are connected with tiger like,"卧虎藏龙"

(Crouching tiger and hidden dragon.) But the equal animal in English is "lion", which often symbolizes " courage, dignity, royalty". We have the "British lion" (大英帝国); "a literary lion"(文学界名人);" the lion’ s share "(最大的部分, 最好的部分) and so on. We usually substitute the “lion” of English with the "tiger" of Chinese in the process of translation.

For example,

(1) a lion in the way 拦路虎

(2) a donkey in a lion' s hide 狐假虎威

(3) to place oneself in the lion' s mouth 置身虎穴

\section{B. Literal Translation}

Literal translation, or direct translation, is the rendering of text from one language to another "word-for-word" (Latin: "verbum pro verbo") rather than conveying the sense of the original. [13](This distinction is valid only when a literal translation does not accurately convey the sense, which is not invariably true.) In translation studies, "literal translation" denotes technical translation of scientific, technical, technological or legal texts.

In translation theory, another term for "literal translation" is metaphrase; and for phrasal (sense) translation "paraphrase."If the source language and the target language have something in common, the skill can be employed like scapegoat, meaning one that is made to bear the blame of others, originated from the Bible, telling a story that an alive goat over whose head Aaron confessed all the sins of the children of Israel on the Day of Atonement. The goat, symbolically bearing their sins, was then sent into the wilderness. And the barking dogs do not bite, to pass fish eyes for pearls as sly as a fox, and a cat has nine lives meaning he who survives from death several times.

For example

(1) Scapegoat 替罪羊 [7]

(2) barking dogs do not bite 吠犬不咬人[7]

(3) to pass fish eyes for pearls 鱼目混珠[7]

(4) as sly as a fox 像狐狸一样狡猾[7]

(5) a cat has nine lives 猫有九条命[7]

As we all know that, some animals has the same feature in both Chinese and English. So literal translation can be employed in translation for the understanding of two peoples.

\section{Free Translation}

Free translation refers to translation according to the meaning of the original, without paying attention to the form and the translation would also be fluent and natural. [10]Free translation includes reconstruction of the original sentences, meaning of the original works, metaphors of the original and so on.

\section{For example}

(1)The woman in charge of the accounts department is an absolute dragon. 


\section{财会科那个女科长是个十足的母夜叉。}

(2)I'm just a rabbit at tennis.

\section{我的网球技术很糟糕。}

In the both two examples, as we all know that the dragon also means a woman who is very ferocious., so here we can use the free translation. There is a proper noun in Chinese culture which directly deludes the woman like that. That is 母夜叉. And in the second example, as we all know that the rabbit means people who is a green hand in a new area, therefor, we can not directly translate the rabbit into 兔子 in Chinese. And the sentence here means that people who are not very good at tennis.

\section{Combination of Free Translation and Literal Translation}

The integration of the two methodology means to find the words of equal value in both source language and target language in each aspect to translate articles. For example the weasel goes to pay his respect to the hen, not with the best intention, and to point to a deer calling it a horse, deliberately misrepresent).

\section{For example}

\section{黄鼠狼给鸡拜年 [12]}

The weasel goes to pay his respect to the hen, not w ith the best intention.

\section{指鹿为马 [12]}

to point to a deer calling it a horse, deliberately misrepresent.

Actually, in the process of translation, many other translational skills can be applied, like foreignization and domestication.

\section{CONCLUSION}

"Language is the exterior performance of the national spirit, while each ethic language is its spirit, vice versa." [14]Idiom items have internal structure. To conclude, in this thesis, I mainly focus on the differences between China and English in culture, and some items have been listed as example to show the gap. Because of the development of the world, words, which are the carriers of culture vary accordingly. "The relevant modality is patently not logical or metaphysical possibility. It suffices that the words are not cognitively possible as determined by the 'laws' of human linguistic competence, whatever they might be."[15]Actually, people's understanding level will change to be aligned with the continuously developing world and will be restricted due to the divergences in geographic environment, historic changes and the technological limitation. Even the same objects will carry different connotation besides language symbols. In translation, the symbol transition is just a form instead of essence rather than key. What matter are not the words but the overtone and other understanding beyond the words themselves.

Though the original purpose of this thesis has been realized, there is still space for improvement. Time and space limit my ability to explore more differences in culture between China and English. It is a pity, but on the other hand, it provides good reasons for further study and research. The thesis itself explores some cultural representatives and some faunal terms, and some color terms are involved,

\section{REFERENCES}

[1] Sapir Edward, An Introduction to the Study of Speech[M]., New York:Harcourt Brace\&Company, 1921; 10

[2] Wang Zhenya. Language and Culture [M]. Beijing: Higher Education Press, 2000.

[3] Deng Yanchang. Language and Culture [M ].Beijing: Foreign Language Teaching and Research Press, 1991: 228

[4] Eugene A Nida. Language, Culture and Translating [M]. Shanghai: Shanghai Foreign Language Education Press, 1999.

[5] Chen Yong,Liu Zhaoyun.A Study on Animal Idioms in English [J].Yibin University Press,2004(3):160-164.1983;40

[6] Cobuild, Collins. Collins Cobuild English Language Dictionary [M]. London: London and Glasgow, 1987.

[7] Zhou Fangzhu, The Cultural Connotations and Translation of Biological Terms [J]. School of Foreign Studies,Anhui University, Chinese Science \& Technology Translators Journal ;48,49,51,52.

[8] http://www.24en.com/column/rhapsodia/2011-05-25/133800.html

[9] Krashen, Affective Filter Hypothesis and Spoken English Teaching.[M], The Alemany press,

[10] http://hi.baidu.com/biofrank/blog/item/5b4c1e3ba31e15e814cecbe2.html

[11] The English-Chinese Dictionary (FIRST EDITION), LU Gusun,Shanghai; Shanghai Translation Publishing House,1975

[12] Yang Limin.Animal and English Idiom [J]. Journal of Anyang Teachers College | J Anyang Teach Coll, 2001 (1):61-62.

[13] Pan Wenguo, Translation and comparative studies. Foreign Literature Studies [M]. Shanghai; Shanghai Foreign Language Education Press, $2005 ; 59$.

[14] N·Wilss, The Science of Translation [M]. Beijing::China Translation \& Publishing Corporation, 1998

[15] Yang Shizhuo, A Course in English-Chinese Translation[M].Beijing; Peking University Press ,2006; 172,2

[16] Lian Shuneng. Comparative Studies of English and Chinese [M]. Beijing; Blue fantasy Book Publishing Co., Ltd., 2004.

[17] Wang Lin, The Study of Western Culture Present and Trends [J]. Journal of Historical Science,2007, 6.

[18] Chen Wenbo. English and Chinese Idioms [M]. Beijing: Foreign Language Teaching and Research Press, 1982. 